\title{
Internships, Workfare, and the Cultural Industries: A British Perspective
}

\section{David Lee}

\author{
University of Leeds, Leeds, UK, d.j.lee@leeds.ac.uk
}

\begin{abstract}
While media work has long been characterized as being structurally dependent on internships, "work experience," and other forms of free labour (Banks 2007; Hesmondhalgh and Baker 2010), the recent shift towards internships has served to normalize what has become known as the media industries "dirty little secret" (Silver 2005). This article contextualizes internship culture within the British cultural industries against a wider political and social frame. Internships and other modes of "apprenticeship" across the British economy reflect a continuation and transformation of national workfare policies, which seek to avert inflationary pressures by coercing people to work or risk losing their welfare benefits. Internship culture has been highly pronounced in the cultural industries and other attractive white-collar sectors such as law and finance (Perlin 2012). Yet, the provision of internships to young people in previously unimaginable contexts such as fast food, retail, and other low-pay service sectors represents a significant shift in policy, compounded by increasingly draconian demands on young people to comply in order to receive state benefits. Discursively, unpaid media work is now seen as an opportunity for the lucky few, rather than a mode of exploitation servicing corporate gain. This has particular relevance for battles over equality and exploitation which have been fought in these sectors, which this discursive shift makes appear increasingly archaic.
\end{abstract}

Keywords: internships, workfare, precarity, cultural industries, neoliberalism, inequality

\section{Introduction}

Over the last ten years, reference to internships has become a familiar refrain in debates around labour in the cultural industries and other professional fields, such as law, accounting, management consultancy, and so forth. These areas are often destination fields for graduates seeking paid labour after many years accumulating debt in an increasingly expensive higher education market (Crawford and Jin 2014). If the "new precariat" is the major emerging class within post-industrial capitalist society (Standing 2011a), then the "intern" has become a poster child for this class, conjuring up images of endless unpaid episodic labour, with the "carrot" of paid, gainful, and, potentially, "creative" work dangled as an elusive reward at the end of it.

This article critically positions the internship phenomenon within a broader politicaleconomic context by considering how this form of labour exploitation fits in with structurally embedded shifts within contemporary modalities of neoliberalism. In particular, it seeks to understand internship labour in relation to established and deepening models of workfarism (Jessop 1995) within advanced liberal economies, as governments seek increasingly punitive and coercive ways to deal with the growing welfare "crisis." As Joanna Figiel argues, we can understand workfarism as the "stick" to the internship "carrot" (2013), yet it is increasingly important to think through the connection between the two in more detail. Are they polar opposites? Is workfarism largely focused on the long-term unemployed, who are recipients of state support? And are internships largely designed for highly educated graduates seeking to enter the professional classes? Or, as "internships" are now "offered" for relatively low-skill, low-pay employment in retail and other segments of the service sector, is the discourse of internships serving to entrench workfarism socially and economically? Does the discursive and political shift away from welfare and towards workfare since the 1970s, particularly in the US and UK, underpin wider changes to labour with a broader acceptance of working for no pay? 
This article provides a synthesis of the political, economic, and social history behind the rise of internships within a new phase of neoliberalism, and the implications of this transformation for the cultural industries. The discursive terrain of the battle against internships has changed, and as it becomes the norm, unpaid media work is seen as an opportunity for the lucky few, rather than a mode of exploitation servicing corporate gain. This has particular relevance for battles over equality and exploitation which have been fought in these sectors, and which this discursive shift makes appear increasingly archaic. The focus of this article is largely on the UK experience, with some discussion of international developments.

\section{From Work Experience to Internships}

Back in the late 1990s, when I left university to seek employment in the television industry in London, the term internship was relatively unknown, and was largely isolated to America, where it had been in circulation since the 1980s (Spradlin 2009). If the term was used in the UK, it "denoted a structured period of experience with a guaranteed stipend" (Winter 2011). At the time, "work experience" was the dominant term for those seeking to enter the highly competitive fields of the creative industries, and this discourse formed the terrain for some key labour conflicts in the 1990s and the early 2000s. "Work experience" was often exploitative, taking advantage of the oversupply of labourers seeking careers in the creative industries; however, there was a shared understanding of what the term meant, and some concessions to workers' rights were made during this period.

In television production, for example, a number of more ethically minded independent production companies had signed up to the voluntary Broadcasting, Entertainment, Cinematograph and Theatre Union (BECTU) agreement that work experience must not last for more than four weeks, and should ideally be paid at the National Minimum Wage; this advice has been adopted far more widely in the television industry since 2007 (BECTU 2009). ${ }^{1}$ When the influential Television Workers' Rights Advocacy Petition (TVWRAP) campaign took shape in the early 2000s and sought to challenge the harsh and exploitative working conditions for young entrants to the television sector in the UK (Saundry et al. 2006, 2007), unpaid "work experience," which often extended over months and even years, was identified as one of the key obstacles to a more equitable creative labour market. TVWRAP actively campaigned against the exploitation and bullying of junior television workers, making use of anonymous testimonies to expose a widespread culture of abuse of workers in the sector. It mounted a successful petition against these conditions and also ran a highly effective media campaign, with a number of stories appearing in the national and industry press during 2004$5 .^{2}$

Since this time, "work experience" has largely disappeared from the lexicon of human resources, replaced with the seemingly more progressive, innocuous term, internship, with its connotations of opportunity, learning, and, crucially, progression.

The term internship first referred to a period of training in the medical profession, and was gradually appropriated by the spheres of politics and business during the 20th century. As Ross Perlin (2012) notes, what had been a preserve for high-prestige graduate recruitment into classic white-collar occupations such as law and finance quickly became far more prevalent during the 1990s, as labour market deregulation and the decline of union membership meant that increasing numbers of companies were seeking competitive economic advantage through the internship route. Most notable during this period is the rise of internships offered in the relatively lower paid, but highly desirable, fields of the cultural industries, in particular, film, broadcasting, and journalism (ibid.). The extent to which internships have become routine is evident in figures published in the 2010 Job Outlook Survey by the National Associa-

\footnotetext{
${ }^{1}$ BECTU is the British trade union for broadcasting, entertainment, and theatre workers. It currently has around 25,000 members.

${ }^{2}$ See www.tvfreelancers.org.uk for full details of the campaign. This was the first internet campaign in British broadcasting history for better working conditions for television production staff, and it received significant coverage in The Guardian and Broadcast. Notably, the campaign was without union involvement, and shows the potential for networks as a means of campaigning. See Saundry et al. (2007) for a full discussion of this campaign, and the implications for trade unions in the audio-visual industries.
} 
tion of Colleges and Employers, which reported that "75 percent of employers prefer job candidates with relevant work experience [and $\mathrm{m}$ ]ore than 90 percent prefer to hire interns or coops who have worked for their organization" (Aoun 2010).

In the UK, the discourse of the internship gained public prominence when the Panel on Fair Access to the Professions, led by Member of Parliament Alan Milburn, reported on the challenges facing social mobility in the UK, and attention turned to the growing number of internships for young graduates, particularly in the high profile fields of media, politics, and law (Cabinet Office 2012). The panel's report provided much needed empirical data on the prevalence of internships in "white-collar" work and argued that these informal arrangements are a key barrier to social mobility, as they exclude potential entrants to professional fields unable or unwilling to take on unpaid work, or lacking the contacts necessary to secure the opportunity of an internship (as well as those without somewhere to live for free within proximity to London while undertaking an internship). The report, and associated debates about "social mobility," elevated the issue of internships to the public and media spotlight, and stories in the national press exposing the conditions of internships became a staple for some months (Prince 2011; Malik 2012). Despite the rich irony of politicians berating the inequity of internships, whilst having benefited from similar arrangements themselves (Prince 2011), the discussion merely reflected what had by then already become a key political-economic reality for many graduates seeking paid employment. However, a number of activist interventions were made, in particular the creation of campaign groups such as Intern Aware and Interns Anonymous (the latter is now defunct, but provided many first-hand accounts of exploitative internships in the UK) and renewed focus was given to the inequities of a culture where the most prestigious jobs demanded extensive unpaid work, and were often facilitated by shared personal and social networks (Lee 2011).

Despite highly vocal campaigns such as Interns Anonymous, Internocracy, Interns Aware, and the Carrotworkers' Collective, internship culture now appears to be embedded within contemporary labour markets. And internships are increasingly being "offered" beyond socalled "white-collar" or "no-collar" work (Ross 2004) in the low-pay service economy, to young people who risk losing their benefits if they refuse the "offer" of work (Malik 2011). ${ }^{3}$ This recent shift of the discourse of internships into the low-pay service economy is significant, indicating not only how the concept of the internship has become normalized within the economy, but also reflecting a mutation in the meaning of the term internship when they are "offered" to individuals in the context of a threat to their social security benefits if they are not accepted. Here, the hitherto voluntary nature of the internship begins to shift to the involuntary arrangements of workfare, which I will outline in the next section.

Making links between workfare and internships means recognizing that there are very different types of "precariat," which, as Guy Standing has argued, encompasses a

multitude of insecure people, living bits-and-pieces lives, in and out of short-term jobs, without a narrative of occupational development, including millions of frustrated educated youth who do not like what they see before them, millions of women abused in oppressive labour, growing numbers of criminalised tagged for life, millions being categorised as 'disabled' and migrants in their hundreds of millions around the world. (Standing 2011b, 1)

In particular, Standing argues there are three clearly identified groups within the precariat:

\footnotetext{
${ }^{3}$ For example, the JobBridge scheme in Ireland, jointly funded by the Youth Employment Initiative, the European Social Fund, and the Department of Social Protection, provides "work experience placements for interns" for six to nine months, and is specifically aimed at the unemployed, who receive an allowance of 50 Euros a week on top of their social welfare entitlement (https://www.welfare.ie/en/Pages/JobBridge-Interns.aspx). Similar programmes in the UK "offer" work experience opportunities which are in fact mandatory: if a claimant is advised to participate in schemes such as The Work Experience Scheme or The Work Programme, they must do so or risk losing their Job Seeker's Allowance. For further details, see http://www.adviceguide.org.uk/wales/work_w/work_selfemployed_or_looking_for_work_e/government_employment_schemes.htm.
} 
The first variety consists of those drifting from working-class backgrounds into precariousness, the second consists of those emerging from a schooling system overcredentialised for the flexi-job life on offer, and the third are migrants and others, such as the criminalised, in a status denying them the full rights of citizens. Each has a distinctive view on life and society. (Standing 2012)

While internships have predominantly been on offer to the second variety, those more highly educated, it seems clear that the language of internships is now impacting on workfare discourse, with unpaid "internships" in supermarkets, call centres, and other traditionally lowpay environments being "offered" as a mandatory requirement for benefit claimants. High profile cases include that of Cait Reilly, a 22-year old geology graduate who stacked shelves at Poundland in Birmingham and was led to believe that her jobseeker's allowance would be cut if she refused to do so (Topping 2012). Absurdly, as Sam Hardy (2014) points out, the National Trust recently offered a Cider and Apple Internship, which essentially meant providing manual labour for free. According to the advertisement, "The work pattern can be flexible with days and hours to suit the harvesting programme with a 30 minute break for lunch. Some occasional weekend work will be required" (National Trust 2014). These examples and the many more that are available (Interns Anonymous 2013), indicate not only how the discourses and practices of the internship have become embedded within British economic life, but also how the terrain of internships has now expanded into workfare politics, with the "carrot" dynamic of the internship increasingly coexisting with the "stick" of punitive measures for individuals on social benefits who refuse the "opportunity."

\section{Workfare and Internships}

In seeking to make links between workfare and internships, it is important to note how workfare has developed and become increasingly normalized within the British economy, following its policy transfer from the United States (Jones 1996, Lindsay and Mailand 2004). Internships and other modes of "apprenticeship" across the British economy reflect a continuation and transformation of workfare policies such as Jobseeker's Allowance instituted under the Conservatives in the 1990s, aggressively pursued under New Labour in the UK, influenced by policies set up under Bill Clinton's presidency. While under New Labour this was achieved through the rhetoric of social inclusion (Jessop 2003), under the ConservativeLiberal Democrat coalition, the justification was largely economic, and often highly gendered (MacLeavy 2011). Workfare politics are being implemented in increasingly radical and coercive forms, driving a hegemonic embedding of policies with the economic aim of averting inflationary pressures by coercing people to work under the threat of incrementally losing their social benefits. It is in the cultural industries that the internship culture has been most pronounced, along with other attractive white-collar sectors such as law and finance (Perlin 2012). Yet, policies designed to provide "apprenticeships" to young people in previously unimaginable contexts (such as fast food, retail, and other low pay service sectors) represent a significant shift in policy, compounded by the imposition of increasingly draconian demands on young people to comply in order to receive state benefits (MacLeavy 2011).

Workfare has a number of definitions. An early, and fairly narrow definition, states that workfare is "[a]ny public welfare program that requires welfare recipients to work (work + welfare $=$ workfare) or to enroll in a formal job-training program" (Shafritz 1988, 595, quoted in Peck 1998). But since the mid-1990s, the term is used far more broadly "to include, as a condition of income support, the requirement that recipients participate in a wide variety of activities designed to increase their employment prospects" (Evans 1995, 75). For the purposes of this paper, workfare is defined as schemes with a mandatory obligation to carry out work or "work-related activity" in order to obtain social welfare payment from the state (Hinton 2012).

Workfare was first coined by civil rights leader James Charles Evers in 1968 and was given mass publicity by US President Richard Nixon in a speech in 1969, who placed it within the politics of welfare reform (Peck 1998, 138). It seeks to offer an alternative to traditional social welfare policies, and in its many different guises, internationally, has a common thread 
which involves welfare recipients providing some form of labour for social welfare benefits. As Jamie Peck argues:

The notion of workfare-particularly where it involves mandatory participation in work or in work programmes - runs counter to established norms of public policy such as passive income support, entitlement, and needs-based provision. So conceived, workfare begins to define an alternative philosophical and political base not only for labour market and social policy ... but also for the structure and strategic orientation of the capitalist state itself. (Peck 1998, 134)

Considered this way, workfare is at the heart of neoliberal governance, shifting responsibility and risk from the state to the individual:

The new imperative is to end welfare, not poverty per se, the objective being to correct those individual behavioural dysfunctions-such as moral laxity, inadequate work discipline-which are seen as a cause of poverty but more importantly as a consequence of the welfare system. (ibid., 136)

Under New Labour, workfare programmes were intensified, although they had first been developed during the Thatcher/Major Conservative period of rule which preceded New Labour's victory in 1997. During the New Labour years, such schemes proliferated and intensified through their three terms of office (1997-2010). As Bob Jessop argues, we can distinguish between the "soft" workfare from 1986, with programmes such as Restart, which invited the unemployed to accept job and training opportunities in return for benefits, and "hard" workfare, which began with the Social Security Act 1989, which forces individuals to look for work and also accept private sector jobs in return for welfare (Jessop 2003, 11). The Jobseeker's Allowance scheme in 1994 and Jobseeker's Act of 1995 entrenched these principles and made it increasingly tougher to access benefits. New Labour embraced these schemes, and Blair promised that New Labour would be a "Welfare to Work Government," claiming that the aim was "to bring [the] workless class back into society and into useful work" (Blair 1997). As Jessop has argued, New Labour policy has been to force the unemployed into the labour market, often into low-wage jobs; as such,

unemployment is no longer seen in terms of a shortage of jobs and hence of a need to manage aggregate demand in order to secure full employment but is interpreted instead in workfarist terms as the product of a shortfall in job-readiness that is reflected in a lack of full employability. (Jessop 2003, 13)

Since the Coalition Government took over from New Labour in 2010, we have seen an even harder line taken in regard to workfare, which is justified through rhetoric around austerity and the stated aim to reduce public spending. Considerable welfare reforms took place on the Coalition's entry into power, culminating in the Welfare Reform Act 2012. In 2011, the number of benefit sanctions imposed upon welfare claimants more than tripled in comparison to 2009 , from 139,000 to 508,000 (Corporate Watch 2012). Ultimately, sanctions arising from a perceived infringement of the terms of an individual's benefit claim, if approved by the Department of Work and Pensions, will lead to the claimant's benefits being stopped. Increasingly, workfare programmes are being contracted out to private providers, and the number of programmes is increasing, with two schemes being compulsory if the claimant is to keep their benefits: the Mandatory Work Activity and Community Action Programme. These programmes have been sharply criticized by journalists on the left as "slave labour" (Toynbee 2012), and as pandering to corporate greed (Clark 2012). And all of this has happened during a period of intensifying class hatred, specifically towards the working class, which has been fuelled by the media and government (Jones 2012).

Of course, there are significant differences between internships and workfare programmes which are aimed at forcing the long-term unemployed to work for no pay, with the threat of a complete withdrawal of their social benefits if they refuse (see Void 2013 for a discussion of 
the differences and similarities). Both are "voluntary," though naturally there is a huge difference between the implications of refusing an internship and refusing to participate in a workfare programme: with the former, the subtext of refusal will be the implicit message that in order to succeed in a knowledge-based economy the internship is a structural requirement, whereas with the latter, the threat is that of the loss of the essential means for subsistence. Still, the parallels are clear: no pay (the normalization of working for nothing), coercion through the discursive threat of failure and material need, and the ongoing, Sisyphean nature of both activities, which function on the basis of the promise of paid employment in the future. Furthermore, as the examples above show, "internships" are becoming part of the language of workfare programmes, alongside the discourse of the "apprentice" (Couldry and Littler 2008).

Paid work seems to be further and further out of reach for interns and for apprentices taking part in workfare schemes. For example, in its expansion of workfare programmes, the UK coalition government offered zero-pay "traineeships" to individuals in order for them to be eligible to gain the opportunity of receiving a place on an unpaid apprenticeship scheme (ibid.). At both the material and discursive level, there is a growing integration of workfare and internships: the unpaid internship as an increasingly prerequisite mandate for those seeking paid employment in the professions and the workfare contract as a mandate for subsistence for those on welfare benefits. Yet the two are often treated separately, particularly by parts of the British political class who have been quick to condemn unpaid internships, but have been actively involved in the development and promotion of workfare programmes for the unemployed (Blears 2013). Underlying this is a deep-seated class hypocrisy, whereby unpaid work for the (largely) middle classes is seen as unacceptable, but perfectly acceptable for those at the more deprived axes of society. Finally, both internships and workfare programmes are structured around conditions and reciprocity, a "something for something" culture, which functions to erode the right to remuneration (Hinton 2012).

\section{Implications}

The rise of unpaid internships within the broader political-economic context of workfare has a number of significant social, cultural, and political implications which demand analysis.

\subsection{Cultural Implications}

Given the prevalence of internships within the cultural industries, we need to consider the cultural and political implications of a further narrowing of the labour pool within these sectors to those who can afford to support themselves without pay for months or years on end. As Kate Oakley (2013), David Lee (2011), Jane Holgate and Sonia McKay (2009), and Doris Ruth Eikhof and Chris Warhurst (2013) have noted, creative work has become a zone of stratification and exclusion for non-white, middle-class entrants. From a normative perspective, this is a major cause for concern, undermining the rhetoric of diversity and equality within the creative industries. Commentators who are unconcerned with the ethical and moral issues involved in this narrowing of the labour pool have shown that there are pragmatic, commercial reasons why diversity is so important in the cultural industries. Creativity and innovation require difference. There is increasing research that shows that the conditions required for creativity to flourish are ones where there is dialogue, difference, and diversity (Amabile et al. 1996). However, this is not simply about making an economic case for diversity, but also a moral case about the kind of culture that is produced. As Chris Land argues in his arresting critique of the film Kingsman, "Middle class, heterosexual, white men will tend to produce films that take their own identity for granted and not even realise that they are making films for people like themselves" (Land 2015). Culture, the means by which we create and circulate shared symbolic forms of expression, is diminished through the reproduction of a highly stratified, homogenous workforce.

As internships proliferate across the cultural sectors, the creative labour market, already highly socially stratified, is becoming ever more so. The normalization of the internship, which favours those with high levels of economic and social capital, is steadily eroding the 
conditions for diversity in the media industries. It also creates a striking mismatch between evidence (that diversity is economically and social important for cultural industries, as cited above), rhetoric (around the creative industries as the "engines" of economic growth and deliverers of socio-economic development free from the social inequalities in work and employment (Florida 2004), and policy (which facilitates the culture of internships and actively promotes the promotion of workfare programmes, as we have seen). Despite the widespread belief amongst policymakers and certain academics that the creative industries have the potential to create a meritocratic world of work (e.g., Howkins 2001), the evidence clearly shows that, in the UK at least, these sectors are still underrepresented by women (38 percent compared to 46 percent of the UK's workforce as a whole) and by ethnic minority workers (five percent compared to nine percent across the UK economy) (Skillset 2010). While data on socio-economic backgrounds is difficult to obtain due to the way in which data is collected by statistical agencies (Randle et al. 2007), we can use higher education degrees as proxies of socio-economic background (Wolf 2002; Eikhof and Warhurst 2013). According to Skillset (2010) figures, over two-thirds of workers in the creative media industries are graduates compared to under 37 percent of the economically active working population in the UK as a whole. Creative workers are also increasingly educated in private schools, particularly in journalism: the last 20 years have seen the percentage of UK leading news journalists educated at private schools rise steadily to 54 percent (compared to seven percent of the overall UK school population) (Sutton Trust 2006).

\subsection{Socio-economic Implications}

The socio-economic implications of internships and their growing alignment with workfare remain unclear as the phenomenon plays out across the contours of a rapidly shifting and uncertain global economic landscape. However, certain factors should be considered. Internships in the professions are largely driven by the oversupply of labour, weak or non-existent unions, and the neoliberal restructuring of the economy, which prioritizes capital accumulation over labour demands. Workfare programmes, as outlined above, are also linked to neoliberalism in terms of the shift from a Keynesian interventionist statist approach (with its principles of universal benefits) to a Schumpeterian welfare state, which focuses on the entrepreneurial individual as the locus of self-responsibility and self-government (Jessop 1995). They offer neoliberal governments a mode of dealing with the "welfare crisis," and place a moral emphasis on labour. Both are based on a belief in entrepreneurialism and the dismantling of labour market regulations which hamper individual development. Yet, both also point to a wider issue, that of transformations in labour markets and the dwindling supply of secure, regularly paid work in advanced capitalism. Other writers have dealt with these issues, and many have posited the crucial importance of a "living wage" to deal with the developing crisis in labour supply.

The debate about a universal basic income has been resurrected in recent years, with a resurgence of interest in the ideas of writers such as Andre Gorz (1999) who advocated a basic income for all, as work was seen to be becoming increasingly automated. Basic income was justified on the basis that it would leave time for all to work less, would be beneficial to society (in terms of community activities and volunteering), and would provide the basis for a more democratic, equal, and just society. There has been a critical backlash against these ideas on the grounds that labour is based on a reciprocal arrangement where money is provided for labour given, whereas the idea of a basic income lacks this quality, as it is unconditional and it is argued that the basic income would impact negatively on work incentivisation and also on labour supply (Tcherneva 2013).

However, in recent years, writers such as Standing (2002), Fran Bennett (2014), and Stephanie Luce (2004) have rejuvenated the discussion, and the political-economic issues at stake are coming more sharply into focus because of the lack of meaningful secure employment for a younger generation accustomed to internships and having grown up with the discourse of workfare rhetoric and activity. Standing has argued that a basic income is an urgent matter of security and a means of addressing the growing inequality crisis on the basis 
of distributive justice (Standing 2002). But he has also argued that it should be nonpaternalistic, and that it needs to be "basic," or otherwise "it leads to indolence and loss of motive to function." Both workfare and internships point to a labour crisis and political crisis which a basic income could help address.

\subsection{Political and Organizational Implications}

Campaigns such as TVWRAP attempted to bring the issues of equality and exploitation in the media industries to the fore nearly ten years ago now. Yet, the rise of internships has worked against many of the advances that were made, undermining the pressure for greater equality and diversity in the media industries, and for more equitable means of accessing employment in these competitive industries.

As a number of writers have explored, the cultural industries remain opaque to enter, exploitative (especially at the entry level jobs), and can cause stress and anxiety for those working in them because of the "club culture" and the long hours worked within precarious employment conditions (Gill 2002; Banks 2007). With the marginalization of unions in the creative industries now widespread, it is left to activists amongst pressure groups, providing first-hand, largely anonymous accounts of work in the internship economy, to try to mobilize for change. Interns Anonymous and Interns Aware are notable in this respect; so too is the writing of Perlin (2012). Yet, as some network-based campaigns have found to their cost, a lack of an organizational base and strong links to unions can hamper efforts to effect meaningful change. For example, TVWRAP, discussed earlier, was ultimately sidelined by the Producers Alliance for Cinema and Television, the influential British media trade association, on the basis that the testimonies were anonymous and therefore unprovable; also the fact that the group was temporary and formed by freelancers meant that it was not able to sustain pressure on employers once the initial press interest had died down (Broadcast Now 2005). As recent research has shown, the issue of exploitation in the British media industries has not disappeared as a result of the TVWRAP campaign, despite its short-term success. For meaningful change to occur, it would surely need legislative and regulatory change against exploitative and iniquitous working conditions, and in the current economic and political climate this seems a distant prospect (Khalsa 2013).

Despite these challenges, there are increasing signs of a cultural and social backlash against the low-pay, no-pay internship culture, particularly amongst educated graduates working in the cultural sector. New collectives such as Bow Arts described by the journalist and author Paul Mason (2014) offer progressive alternatives to the labour crisis by allowing individuals to work for themselves, but within a shared co-operative space. New organizations are emerging, such as AltGen, which indicate new possibilities for a generation frustrated and jaded by the harsh economic contours of contemporary British life (ibid., 2014). Furthermore, anti-workfare campaigning is becoming more widespread and vocal, with groups such as Boycott Workfare (http://www.boycottworkfare.org/) providing online resources, organizing boycotting activities, and "naming and shaming," or exposing the often dubious practices of the private companies delivering such programmes on behalf of the public sector. While there is little evidence as yet of formal links between anti-internship and antiworkfare activists, it appears that they are being critically linked at the discursive level, as evidenced by recent articles on the blogs of anti-workfare campaigners (Void 2013; Arky 2013). The pressing need to forge a link between workfare and internships can be clearly detected in these articles; for as "Ann Arky" (2013) argues in relation to employers making use of intern and workfare labour, "They are both doing the same thing, exploiting free labour." However, currently the depth of analysis offered by such articles is limited, and fails to establish a programme by which these two different activist groups could be linked. This would involve the need for thinking through the commonalities and differences between workfare and internships. There is indeed critical power in Void's statement:

About the only real difference between unpaid internships and work experience schemes is that internships usually lead to well paid careers in popular sectors like fashion, the media or entertainment. In contrast Work Experience generally leads back to the dole as 
grasping employers maintain a rolling stock of free workers instead of paying wages. (Void 2013)

However, in my view, it is also necessary to think about internships and workfare programmes in a way, which does not play down the significant divergences between these two groups of exploited labour. It is only through establishing commonalties but also acknowledging differences that we can begin to forge a shared politics of the precariat which rejects such exploitation on normative grounds, and which both groups might identify with and support.

\section{Conclusion}

This article has sought to make links between workfare and internship culture in the hope that it will provide a shared resource for the many disparate elements of the "new precariat." While it may be hard to imagine a shared politics between groups as diverse as media interns and street cleaners, as Standing points out, all groups of the precariat are experiencing the sharp end of the accumulation crisis, the crisis of contemporary labour markets, and the prospect of "recovery without jobs," and, as such, need to find common cause if a progressive politics is to emerge from the current context (Standing 2011a). Workfare programmes are an attempt to "fix" neoliberal capital accumulation and act against inflationary pressures. Internships are a phenomenon of often unpaid labour that provides companies with a ready, educated labour supply. Both workfare programmes and internships erode individual security, and this is not without social risk. As Standing has argued, the politicization of the precariat may have potentially worrying prospects, with neofascism on the increase globally, as it offers some form of security to neoliberalism's "others" (ibid.).

In a recent article, John Lanchester reflected on the increasing automation of work, previously carried out by humans and now being done by robots (Lanchester 2015). In a wideranging analysis, which considers the use of robots in Amazon's "fulfilment centres," Google's driverless cars, as well as the political-economic implications of Apple's recent firstquarter profit announcement (\$74.6 billion in turnover, $\$ 18$ billion in profit), Lanchester considers the human cost of improved "productivity." For example, Apple is now the most profitable business in the world; in the past it was Ford Motors. Yet Apple employs 92,600 workers, while Ford employed 600,000 (ibid.). As he argues, "Capital isn't just winning against labour: there's no contest. If it were a boxing match, the referee would stop the fight" (ibid.).

Given this context, and that outlined above in the discussion of workfare and internships, what might be the political ways forward for a more progressive approach to labour markets which are rapidly transforming under conditions of technological innovation? Most immediately, diagnosis of the problem needs to lead to political mobilization on these issues. Greater discussion is needed about the hypocrisy of politicians who are quick to condemn internships for the middle and upper classes, but happy to promote workfare programmes. This tells us a great deal about the inequities within contemporary politics on work and labour. But we also need new ways of thinking about work and society, which draws on the new possibilities that automation might provide for greater human flourishing and social justice. It may be too optimistic to suggest, as Lanchester does, that this could lead to an "alternative future" which "would be the kind of world dreamed of by William Morris, full of humans engaged in meaningful and sanely remunerated labour" (Lanchester 2015). However, as William Davies (2014) has argued, there are increasing signs of progressive movements which seek to find new ways of working and living that look beyond the limits of neoliberalism.

\section{References}

Amabile, Teresa, Regina Conti, Heather Coon, Jeffrey Lazenby and Michael Herron. 1996. Assessing the Work Environment for Creativity. Academy of Management Journal 39 (5): 1154-1184.

Arky, An. 2013. Internship-Workfare Exploitation. Accessed January 13, 2015. http://radicalglasgowblog.blogspot.co.uk/2013/04/internship-workfare-exploitation.html.

Auon, Joseph. 2010. Protect Unpaid Internships. Inside Higher Education. Accessed June 12, 2014. http://www.insidehighered.com/views/2010/07/13/aoun. 
Banks, Mark. 2007. The Politics of Cultural Work. London: Palgrave.

BECTU. 2009. Work Experience Guidelines. London: BECTU.

Bennett, Fran. 2014. The "Living Wage," Low Pay and In Work Poverty: Rethinking the Relationships. Critical Social Policy 34 (1): 46-65.

Blair, Tony. 1997. Speech at the Aylesbury Estate, June 2, Southwark, London.

Blears, Hazel. 2013. Name and Shame Firms which Employ Unpaid Interns, says Hazel. Accessed January 3, 2015. http://www.hazelblears.co.uk/news/name-and-shame-firms-which-employ-unpaidinterns-says-hazel.

Broadcast Now. 2005. Pact Rejects Compulsory Code for Indies. Accessed January 8, 2015. http://www.broadcastnow.co.uk/pact-rejects-compulsory-code-for-indies/1025206.article.

Cabinet Office. 2012. Fair Access to Professional Careers: A Progress Report by the Independent Reviewer on Social Mobility and Child Poverty. London: Cabinet Office.

Clark, Warren. 2012. A World on Workfare. New Internationalist 453: 38-39.

Corporate Watch. 2012. Revealed: The Punishing Reality of the Coalition's Welfare Reforms. Accessed August 17, 2012. http://www.corporatewatch.org/?lid=4371.

Couldry, Nick and Jo Littler. 2008. The Work of Work: Reality TV and the Negotiation of Neoliberal Labour in The Apprentice. In Rethinking Documentary: New Perspectives and Practices, edited by Thomas Austin and Wilma de Jong, 258-267. Maidenhead: Open University Press.

Crawford, Claire and Wenchao Jin. 2014. Payback Time? Student Debt and Loan Repayments: What Will the 2012 Reforms mean for Graduates? London: Institute of Fiscal Studies. Accessed June 10, 2014. http://www.ifs.org.uk/comms/r93.pdf.

Davies, William. 2014. The Limits of Neoliberalism: Authority, Sovereignty, and the Logic of Competition. London: Sage.

Eikhof, Doris and Chris Warhurst. 2013. The Promised Land? Why Social Inequalities are Systemic in the Creative Industries. Employee Relations 35 (5): 495-508.

Evans, Patricia. 1995. Linking Welfare to Jobs: Workfare, Canadian Style. In Workfare: Does it Work? Is it Fair?, edited by A. Sayeed, 75-104. Montreal: Institute for Research on Public Policy.

Figiel, Joanne. 2013. Class Action or Class Struggle? ephemera: theory \& politics in organization 13 (4): 903-910.

Florida, Richard. 2004. The Rise of the Creative class and How It's Transforming Work, Leisure, Community and Everyday Life. New York: Basic Books.

Gill, Ros. 2002. Cool, Creative, and Egalitarian? Exploring Gender in Project-based New Media Work in Europe. Information, Communication \& Society 5 (1): 70-89.

Gorz, Andre. 1999. Reclaiming Work: Beyond the Wage-based Society. Oxford: Blackwell.

Hardy, Sam. 2014. There is No Such thing as a "Cider and Apple Juice Internship." There is Only Unpaid Manual Labour. Accessed July 20, 2014. http://unfreearchaeology.wordpress.com/2014/07/08/free-archaeology-internship-national-trustunpaid-manual-labour/.

Hesmondhalgh, David and Sarah Baker. 2010. "A very complicated version of freedom”: Conditions and Experiences of Creative Labour in Three Cultural Industries. Poetics 38 (1): 4-20.

Hinton, Eleanor. 2012. The Social and Political Significance of Workfare in the United Kingdom. Unpublished Masters thesis. London: School of Advanced Study.

Holgate, Jane and Sonia McKay. 2009. Equal Opportunities Policies: How Effective are they in Increasing Diversity in the Audio-visual Industries' Freelance Labour Market? Media, Culture \& Society 31 (1): 151-163.

Howkins, John. 2001. The Creative Economy. London: Penguin.

Interns Anonymous 2013. Accessed July 20, 2014. http://internsanonymous.co.uk/.

Jessop, Bob. 1995. Towards a Schumpeterian Workfare Regime in Britain? Reflections on Regulation, Governance, and Welfare State. Environment and Planning A 27 (10): 1613-1626.

Jessop, Bob. 2003. From Thatcherism to New Labour: Neo-Liberalism, Workfarism, and Labour Market Regulation. In The Political Economy of European Unemployment: European Integration and the Transnationalization of the Employment Question, edited by Henk Overbeek, 137-153. London: Routledge.

Jones, Martin. 1996. Full Steam Ahead to a Workfare State? Analysing the UK Employment Department's Abolition. Policy \& Politics 24 (2): 137-157.

Jones, Owen. 2012. Chavs: The Demonization of the Working Class. London: Verso.

Khalsa, Balihar. 2013. Bectu Survey Highlights "Exploitation" in Factual. Accessed January 8, 2015. http://www.broadcastnow.co.uk/bectu-survey-highlights-exploitation-in-factual/5051265.article. 
Lanchester, John. 2015. The Robots are Coming. London Review of Books 37 (5). Accessed March 20, 2015. http://www.Irb.co.uk/v37/n05/john-lanchester/the-robots-are-coming.

Land, Chris. 2015. The Cinematic Spectacle that Class War has Become. Accessed March 20, 2015. http://staffblogs.le.ac.uk/management/2015/03/18/the-cinematic-spectacle-that-class-war-hasbecomel.

Lee, David. 2011. Networks, Cultural Capital, and Creative Labour in the British Independent Television Industry. Media, Culture \& Society 33 (4): 549-565.

Lindsay, Colin and Mikkel Mailand. 2004. Different Routes, Common Directions? Activation Policies for Young People in Denmark and the UK. International Journal of Social Welfare 13 (3): 195-207.

Luce, Stephanie. 2004. Fighting for a Living Wage. Ithaca, NY: Cornell University Press.

MacLeavy, Julie. 2011. A "New Politics" of Austerity, Workfare, and Gender? The UK Coalition Government's Welfare Reform Proposals. Cambridge Journal of Regions, Economy, and Society 4 (3): 355-367

Malik, Shiv. 2011. Young Jobseekers Told to Work without Pay or Lose Unemployment Benefits. The Guardian. Accessed July 30, 2014. http://www.theguardian.com/society/2011/nov/16/youngjobseekers-work-pay-unemployment.

Malik, Shiv. 2012. Internships Should be Subject to Labour Market Rules, says Social Mobility Tsar. The Guardian. Accessed January 8, 2015. http://www.theguardian.com/society/2012/may/30/internships-labour-market-social-mobility.

Mason, Paul. 2014. The Young, Skint, and Self-employed Need a Radical New Labour Market. The Guardian. Accessed July 24, 2014. http://www.theguardian.com/commentisfree/2014/jul/20/youngskint-self-employed-new-labour-market.

National Trust. 2014. Cider and Apple Intern. Accessed July 24, 2014. http://www.nationaltrustjobs.org.uk/join-us/search?job-type=\&regionoptions $=0 \&$ seasonal role num $=63 \&$ vacancy reference $=63$.

Oakley, Kate. 2013. Making Workers: Higher Education and the Cultural Industries Workplace. Cultural Work and Higher Education, edited by Daniel Ashton and Caitriona Noonan, 25-44. London: Palgrave.

Peck Jamie. 1998. Workfare: A Geopolitical Etymology. Environment and Planning D: Society and Space 16 (2): 133-161.

Perlin, Ross. 2012. Intern Nation: How to Earn Nothing and Learn Little in the Brave New Economy. London: Verso.

Prince, Rosa. 2011. Nick Clegg: I was Wrong to use Father's Help to Secure Bank Internship. The Telegraph. Accessed July 29, 2014. http://www.telegraph.co.uk/news/politics/nickclegg/8430087/Nick-Clegg-I-was-wrong-to-use-fathers-help-to-secure-bank-internship.html.

Randle, Keith, Leung Wing-Fai and Juno Kurian. 2007. Creating Difference: Overcoming Barriers to Diversity in UK Film and Television Employment. University of Hertfordshire: Creative Industries Research and Consultancy Unit. Accessed June 29, 2014. http://researchprofiles.herts.ac.uk/portal/en/publications/creating-difference-overcoming-barriers-todiversity-in-uk-film-and-television-employment\%2810b5867a-7129-4e20-a9b50d469ba7f566\%29.html.

Ross, Andrew. 2004. No-Collar: The Humane Workplace and its Hidden Costs. Philadelphia: Temple University Press.

Saundry, Richard, Mark Stuart and Valerie Antcliff. 2006. "It's More than Who you Know": Networks and Trade Unions in the Audio Visual Industries. Human Resource Management Journal 16 (4): 376-392.

Saundry, Richard, Mark Stuart and Valerie Antcliff. 2007. Broadcasting Discontent-Freelancers, Trade Unions, and the Internet. New Technology, Work and Employment 22 (2): 178-191.

Shafritz, Jay. 1988. The Dorsey Dictionary of American Government and Politics. New York: Dorsey Press.

Silver, James. 2005. Exploitation is More Widespread than Ever. The Guardian. Accessed March 20, 2014. http://www.theguardian.com/media/2005/apr/11/broadcasting.mondaymediasection.

Skillset. 2010. Creative Media Workforce Survey 2010. London: Skillset.

Spradlin, Isaac. 2009. The Evolution of Interns. Forbes. Accessed May 2, 2014. http://www.forbes.com/2009/04/27/intern-history-apprenticeship-leadership-careers-jobs.html.

Standing, Guy. 2002. Beyond the New Paternalism: Basic Security as Equality. London: Verso.

Standing, Guy. 2011a. The Precariat: The New Dangerous Class. London: Bloomsbury. 
Standing, Guy. 2011b. The Precariat: The New Dangerous Class. Policy Network Essay. Accessed July 20, 2014. http://www.policy-network.net.

Standing, Guy. 2012. The Precariat and Why it Needs Deliberative Democracy. Open Democracy. Accessed July 20, 2014. https://www.opendemocracy.net/guy-standing/precariat-why-it-needsdeliberative-democracy.

Sutton Trust. 2006. The Educational Background of Leading Journalists. London, Sutton Trust.

Tcherneva, Pavlina. 2013. The Job Guarantee: Delivering the Benefits that Basic Income Only Promises-A Response to Guy Standing. Basic Income Studies 7 (2): 66-87.

Topping, Alexandra. 2012. Workfare that Shames UK plc, or a Left-wing Plot by the Job Snobs? The Guardian. Accessed July 14, 2014. http://www.theguardian.com/society/2012/feb/28/workfare-ukplot-job-snobs.

Toynbee, Polly. 2012. Protest Really Does Work-Just Look at Tesco and Workfare. The Guardian. Accessed July 21, 2012. http://www.guardian.co.uk/commentisfree/2012/feb/22/protest-tescoworkfare.

Void, Johnny. 2013. Wages for Interns, Workfare for the Poor, says Jo Swinson MP. Accessed July 20, 2014. http://johnnyvoid.wordpress.com/2013/11/11/wages-for-interns-workfare-for-the-poorsays-jo-swinson/.

Winter, Anna. 2011. Intern Nation by Ross Perlin-Review. The Guardian. Accessed June 2, 2014. http://www.theguardian.com/books/2011/may/15/intern-nation-ross-perlin-review.

Wolf, Alison. 2002. Does Education Matter? London: Penguin.

\section{About the Author}

David Lee

David Lee is a Lecturer in Cultural Industries and Communication in the School of Media and Communication at the University of Leeds. He is the author of a number of articles and chapters on creative work, cultural policy, copyright, and television studies in international journals including the International Journal of Cultural Policy; Cultural Trends; Media, Culture \& Society; and Television and New Media. Before working in academia, David worked in documentary production, on series such as Newsnight, Panorama, and The Money Programme. 